\title{
Aeromagnetic Study of Oil Seepage along the Basement Flanks of Part of the Lower Benue Trough, South Eastern Nigeria
}

\author{
Obi, D.A ${ }^{1}$ Ilozobhe, A. J. ${ }^{2}$ Lebo, S. E. ${ }^{3}$ \\ ${ }_{1}^{1 \&, 3}$ Department Of Geology University Of Calabar \\ ${ }^{2}$ Department Of Physics University Of Calabar
}

\begin{abstract}
Two aeromagnetic total intensity field maps on a scale of 1:100,000 covering parts of Abakaliki and Bansara in Ogoja sub basin of the lower Benue trough were digitized and processed using manual and computer techniques, including polynomial filtering, Petter's half slope, maximum slope, frequency distribution, and 2.5D forward and inverse modeling. The manual result indicate depth to magnetic basement of shallow areas ranging from $0.5 \mathrm{~km}$ to $2.0 \mathrm{~km}$ and deeper sources between $2.0 \mathrm{~km}$ to $3.5 \mathrm{~km}$. Also forward and inverse saki modeling results indicate shallow depths of $0.8 \mathrm{~km}$ to $1.1 \mathrm{~km}$ and deeper sources between $1.5 \mathrm{~km}$ to $2.6 \mathrm{~km}$. The major lineament trends in the NE-SW orientation with a major fracture trend of $38 \mathrm{~km}$ coinciding with the position of the suppose oil seepage. The Mfum areas within the Bansara has the highest sediments thickness ranging 2.6-3.5km. This area also forms the beginning of the fracture trend towards the oil seepage, which may be the direct evidence of migration of hydrocarbons towards the basement flanks and exposed as a seepage.
\end{abstract}

Key words: polynomial filtering, lineament, seepage, magnetic basement

\section{Introduction}

Hydrocarbon seepages are visible evidence at the earths surface of the presence or past leakages of oil or gas from the subsurface, oil seepages are particularly important to exploring new basins or areas Magbon, L. B and Dow, W. H. (2002).

In February 2011, there was a report of a suppose oil discovering in a small stream as the villagers were mining sand for building purpose, this was between Nsadop and Isobendeghe communities close to the AfiBoje hills of Cross River State. The dark substance was said to smell hydrocarbon and that vegetation cover hardly occur to about 100 meters within the suppose seepage area. The stream was also said not have any aquatic life. The above information was the basis to carry out this study and to find out if magnetic evidence support the presence of hydrocarbons within the flanks of basement terrains, since the suppose communities were located within the basement complex.

The area of study lies within latitude $6^{0} .00-6^{0} 30^{\prime} \mathrm{N}$ and longitude $8^{0} .00-9^{0} .00 \mathrm{E}$ and has an area of approximately 5, $412 \mathrm{sqkm}$, these include villages around Abakaliki, Bansara, Edor, Nkum, Boje, Nsadop and it's adjourning areas (fig 1.0). The above locations forms part of the lower Benue Trough (Ogoja sub-basin), and it is adjourning Baminda Massif complex. The lower Benue trough is a linear intracratonic basin and it's origin associated with the separation of African and South American continents in the early cretaceous Nwachukwu (1972), Fairhead and Okereke (1987), Benkhelil et; al (1982). Geophysical Investigations of the lower Benue trough have been carried out by several workers Adighije, (1981), Okereke, C. S. and Ofoegbu C. (1989), their work was on a regional reconnaissance framework and had depths estimate from Abakaliki anticlinorum to the Ogoja areas ranging between $2500 \mathrm{~m}$ to $5000 \mathrm{~m}$. This present study involves subsurface modeling, intrasediment to basement fractures and their relationship and oil seepage along the flank of Afi basement Massifs.

\section{Geology of the Study Area}

The study area forms part of the lower Benue Trough sitting on the Afi- Baminda Massif. The Precambrian basement rocks which comprises of Gneisses, migmatites and granites are the oldest rocks which are exposed around Okundi, Nsadop and Boje areas, these rocks are unconformably overlain by sediments of the Asu-River group (Albian-Cenomanian). Detail stratigraphic work reveal a stratigraphic column which ranges from middle Albian-Maastritchtian with albian sediments about $1400 \mathrm{~m}$ of sandy conglomeritic materials (Ojoh, 1992), this unit is further overlain by the (Turonian) Eze-Aku formation which consist of black shales and black shales beds intercalated within predominantly sandy units (Reyment, 1965). These units are exposed along Edor, Nkum, Obubra, Mfum and Bansara villages. The tertiary basalts are the most recent rocks which intrudes the Eze-Aku formation (Fig 2). 


\section{Data Analysis}

The acquired aeromagnetic data was analysed manually and with computer processed methods. The aeromagnetic maps were in $0.5^{0} \times 0.5^{0}$ (half by half) degrees, and on a scale of $1.100,000$. The flight lines separation was $2 \mathrm{~km}$ intervals with tie lines separation of $20 \mathrm{~km}$ intervals.

Digitization of each aeromagnetic map was alone along flight line orientation at an interval of $1 \mathrm{~km}$ to minimize the problem of frequency aliasing. The format for digitization was that of the United States geological surveys potential field softwares version 2.2. The process of digitization involves extracting the coordinates at each created fudicial point for $\mathrm{X}, \mathrm{Y}, \mathrm{Z}$, where $\mathrm{X}$ is the longitude, $\mathrm{Y}$ is the latitude and $\mathrm{Z}$ is the total magnetic field. The extraction process had a total of 2620 data points from the two map which was subsequently used for further computer processing.

The computer processed data was analysed through a series of software programmes starting with map merging where the two X, Y, Z files from both maps were map merged using the G merge software. Since both maps had the same flying elevation $(500 \mathrm{ft})$, the output gave a single grid file (Boki grd). The grid file was then subjected to reduction to the pole to center the individual anomalies using F-Rtp software programme. The output grid file was subsequently contoured to produce the Reduced -To-The-pole magnetic map of the study area (Fig. 3). The merged grid file was subjected to filtering by polynomial method using the surfit software programme to separate the residual and regional fields (Phillips 1997). The output grid data of the residual field was then contourd with a "PC contour" software programe to produce the residual map of the study area (fig. 4). Further processing was done by using the residual grid file for subsurface modeling. The profile $-\mathrm{X}, \mathrm{P}-\mathrm{depth}$, and Saki software programme were used for both forward and inverse $2.5 \mathrm{D}$ modeling. Three (3) profiles were extracted in perpendicular direction to observed magnetic anomalies, the extraction was done by using the software programme profile- $\mathrm{X}$, this was then used as an input file to the P-depth software programme which does the forward modeling. The modeling parameters include; inclination, declination, total filed, Azimuth, no of bodies, and assumed depth of placed bodies (Table 3). The above parameters were used to generate a calculated curve that best fit the observed curve and when the root mean square error (RMS) is ten than $5 \%$ a forward model profile is created prior to the inverse Saki modeling.

The inverse modeling Saki software, utilizes the forward model created file from P-depth, and with input parameters same as in forward modeling, a series of mathematical iterations are made and with several iterations the root mean square error is reduced to a minimal $1.0 \%$ indicating an almost perfect model of the subsurface (Figs.5, 6 7). Manual data analysis was also employed in this study, this involves lineaments trends analysis and depth to source of magnetic anomaly estimation. The process of lineament trend extraction involves identifying all the anomalies on the hard copy maps and placing an overlay to trace all the anomalies. The extracted parameters include anomaly width, length, orientation and closure amount, these parameters were also used to produce the frequency distribution of lineaments in both sheets (tables 1 and 2). The result of the percentage of normalized lengths of anomalies was plotted as rosette diagrams using sufer 9.0 software (fig. 8.a,b). These diagrams represent the dominant lineaments trends and fracture patterns in the study area.

Manual depth to source of magnetic anomaly was done using petter's half width and maximum slope methods. The technique involves selecting profile lines along prominent anomalies and digitized for distances in kilometers and total magnetic fields along the profile lines. The output of the plot is a graphical presentation of the plot from which the half width and maximum slope techniques are employed to determine depth estimates. A total of ten (10) profiles were selected and analysed and the results indicate thirty (30) depth points ranging from $0.5-3.5 \mathrm{~km}$. These depth estimates were repositioned to their X, Y coordinates and contoured using sufer 9.0 software programe to produce the subsurface depth map of the study area (Fig. 9).

\section{Results / Discussion}

The three profiles choosen for modeling covered the study area one was choosen along the Abakaliki axis, while two were along the suppose seepage area. The Abakaliki profile A (Fig.5) was for comparison to that of the Bansara areas, it has a total distance of $20 \mathrm{~km}$ and a sediment thickness which range between $0.8-2.3 \mathrm{~km}$. The Bansara area had two profiles (B and C), one at Mfum and the other at Edor towards the fracture zone area. The Bansara (Nkum) profile B (fig. 6) has a distance of $21.6 \mathrm{~km}$ with a depth range between $1.5-2.6 \mathrm{~km}$. While the Bansara - Nsadop Profile C (Fig.7) along the fracture zone has a distance about $20.00 \mathrm{~km}$ with depth range between $1.0-1.6 \mathrm{~km}$. The above results indicate that the basin shallows at the Abakaliki axis and deepens towards the Bansara-Mfum axis with a progressive thinning out towards the basement hills of Bansara Boje areas.

There is a collaborating agreement in depth to source of anomaly in both the saki modeling and manual depth estimates which indicate a general increament in sediments thickness from the Abakaliki areas which increases at the Bansara (Mfum) areas and shallows out at the Bansara Edor towards the Boje hills (Fig 5, 6,7, 9). 
The major lineament trend in the study area is in the NE-SW orientation (Fig 8, a,b). This is evident in the longest fracture trend around Mfum, with a distance of about $38.0 \mathrm{~km}$. The dommaint frequency in the Abakaliki areas (fig 8a) range between $51^{\circ}-60^{\circ}$ with a percentage lineaments trend of $35 \%$. The Bansara area (fig $8 \mathrm{~b}$ ) has a domiant orientation of lineament between $71^{\circ}-80^{\circ}$ with a percentage frequency of $26 \%$. However, the longest trend of $38 \mathrm{~km}$ trends NE -SW directly towards oil seepage area.

The depth result from saki modeling and manual methods support (sediment accumulation ranging between $2.6-3.5 \mathrm{~km}$, within Mfum areas these depth extimates supports hydrocarbon generating where other conditions are favourable. The occurrence of the presence of the longest fracture zone at this location further support the evidence that hydrocarbons might have migrated along this fracture zone and exposed at the flanks of the basement (Nsadop - Boje) axis (Gibson et al 1998). Also, the study area reveal the presence of (7) seven intrusives which are made of basalts and Rhyolites (Table 3). The presence of these intrusives within this subbasin may generate over mature source rocks which may produce more gas than oil.

\section{Summary/ Conclusion}

Oil seepages are leakages of oil and gas from the subsurface to the surface, they may be identified on magnetic maps to form traps with low magnetic susceptibilities (Gibson R. I. and Millegan P. S. 1998, Machel, H. G. and Burton, E. 1991). Oil and gas can change near surface susceptibilities through magnetic alterations of clays, pyrohotite and pyrite magnetic minerals (Machel H. G. and Burton, E. 1991). The above evidence in also seen along the suppose fault zone as there is a significant drop in magnetic susceptibilities along this zone which drops from 7850-7780 gammas, this significant drop in magnetic susceptibilities supports the presence of a fault and possible presence of hydrocarbons other evidence of possible hydrocarbon generation within the area is the high depth of sediment accumulation around Mfum reaching 2.6-3.5km, which occurred at the base of the fracture area and extends towards the exposed oil seepage.

Conclusively, the study reveals the presence of a possible oil seepage as claimed by the villagers. It's recommended that Geochemical and further geophysical investigations be made to explore for possible hydrocarbon deposits within the area.

\section{References}

[1]. Adighije, C. T. (1981). Gravity study of the lower Benue Trough, Nigeria. Geol. Mag., 118 (1), $59-67$.

[2]. Benkhelil, J. (1982). Benue Trough and Benue Chain. Geological Magazines 119; $115-118$

[3]. Fairhead, T. D and Okereke, C. S. (1987). A regional gravity study of the West African Rift System in Nigeria and Cameroon and its implication Tectonophysics 143, 141-159.

[4]. Gibson, R. T. and Millegan, P. S. (1998) Geological application of gravity and magnetics: Case histories, society of exploration Geophysics.

[5]. Machel, H. G. and Burton, E. (1991). Chemical and Microbial processes causing anomalous magnetization in environments affected by hydrocarbon seepage. Geophysics, $56,598-605$.

[6]. Magoon, L. B. and Dow, W. G. (2002). The petroleum system from source to trap. American Association of Petroleum Geologist, Tulsa, Oklahoma, USA.

[7]. Nwachukwu, S. O. (1972). The techonic evolution of the Southern Portion of the Benue Trough, Nigeria. Geol. Mag, 109, pp. 411419.

[8]. Ojoh, K. A. (1992). The Southern Part of the Benue Trough (Nigeria) Cretaceous Stratigraphy, Basin analysis, paleo-oceano graphy and Geodynamics evolution in equatorical domain of the South Atlantic Nigerian Association of Petroleum explorationist Vol. 7 No 2. P 131-152.

[9]. Okereke, C. S. and Ofoegbu, C. O. (1989). Gravity and Magnetic data over the Yola cum of the upper Benue Trough (1989). In C. O. Ofoegbu (Ed). The Benue Trough, structure and Evolution (pp. 161-169). Braun Schwlg. Viewey and Sohn.

[10]. Phillips, J. D. (1997). Potential field geophysical software for the PC version 2.2 U.S Geological Survey Open file Report. 97 - 725 , $1-32$.

[11]. Rayment, R. A. (1965). Aspect of Geology of Nigeria. Univ. Ibadan Press, Nigeria pp. 1-145. 


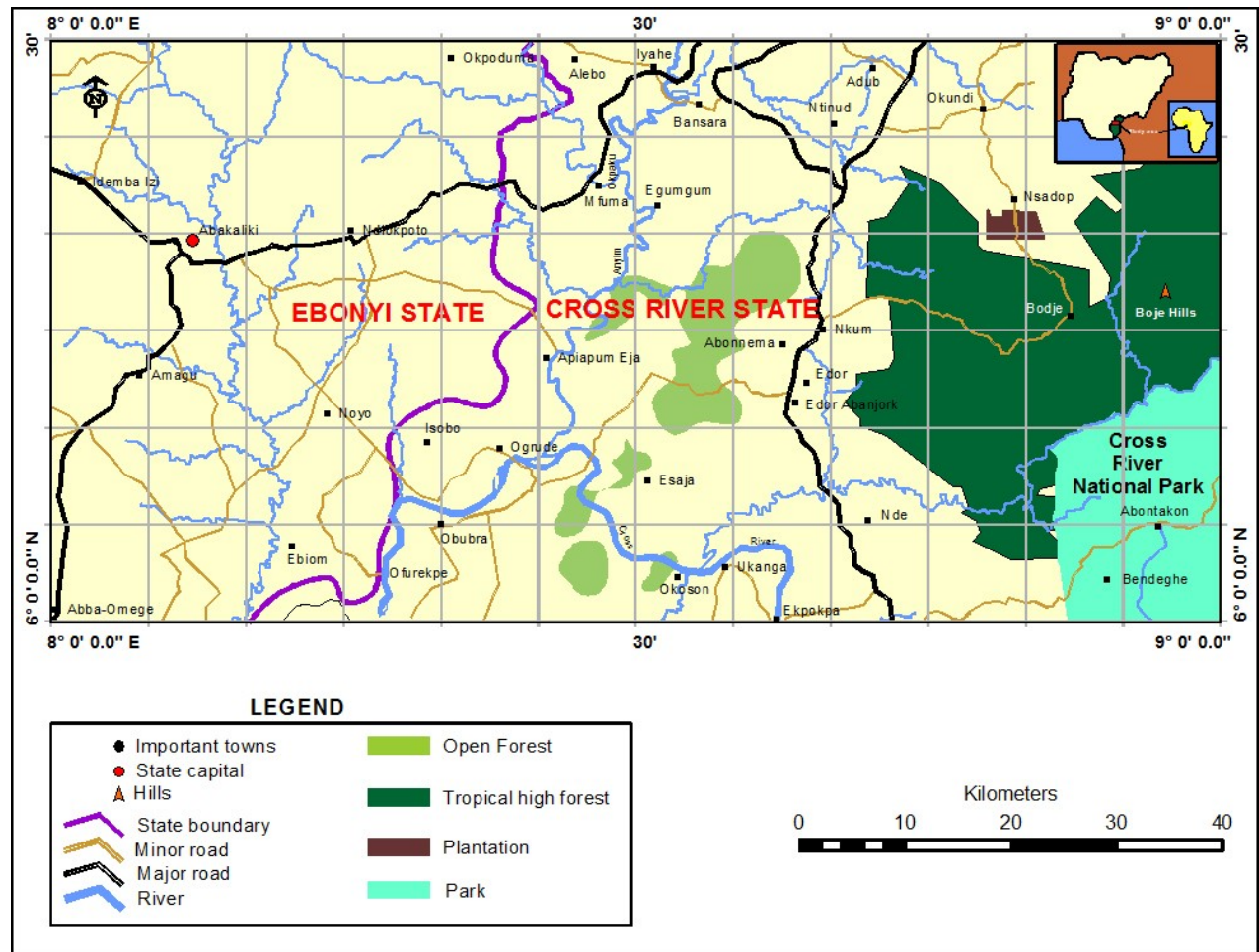

Fig. 1 LOCATION MAP OF THE STUDY AREA

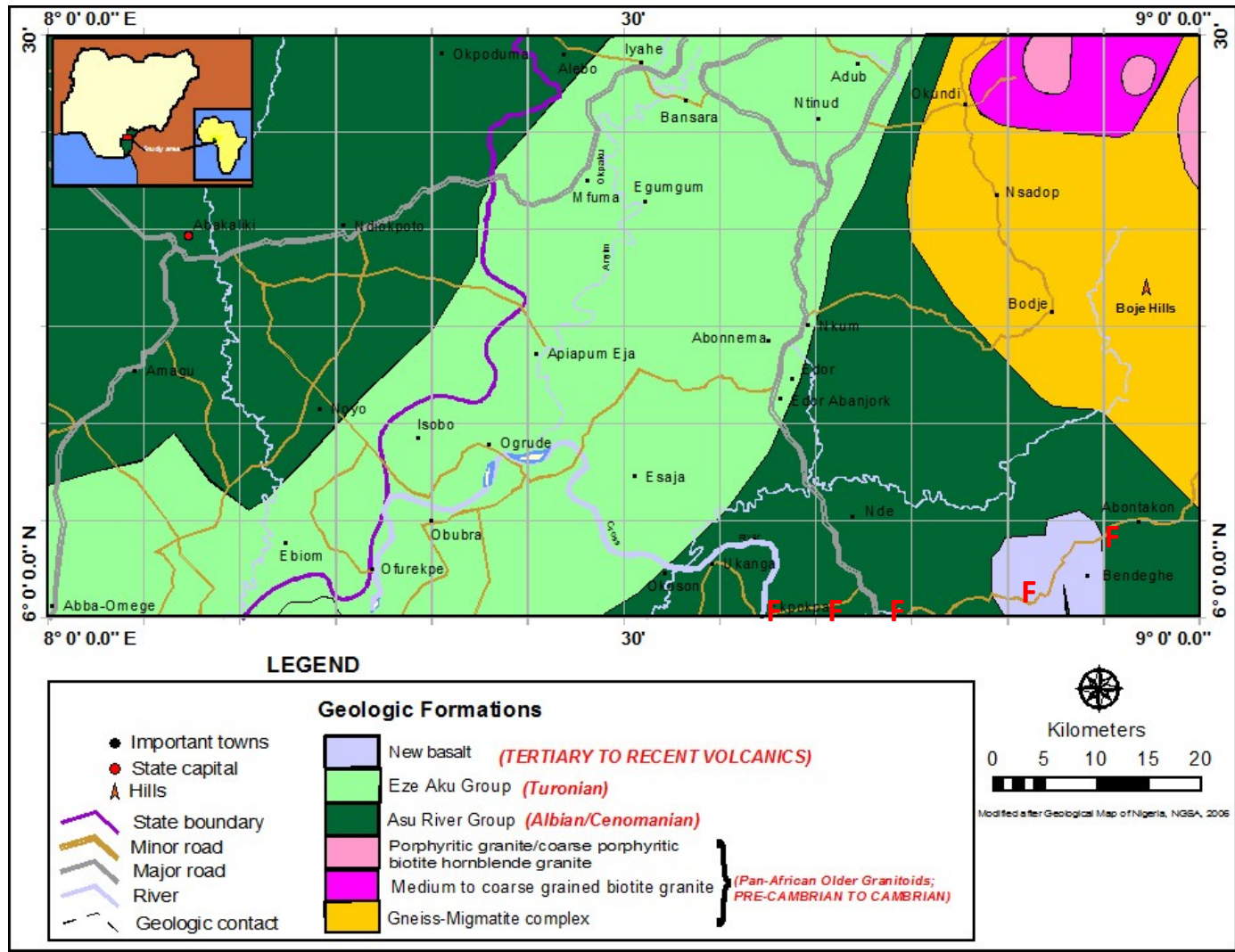

Fig 2 GEOLOGIC MAP OF THE STUDY AREA( MODIFIED AFTER NGSA1994) 


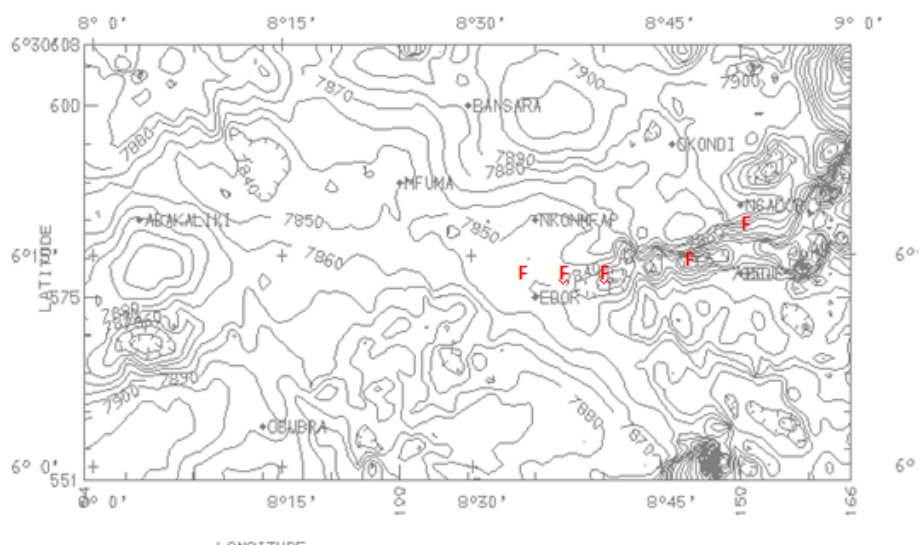

Fig. 3 REDUCED - TO - THE- POLE MAGNETIC MAP FROM TOTAL INTENSITY FIELD( ADD $25,000 \mathrm{nT}$

TO CONTOURS WHICH ARE AT INTERVALS OF 10nT

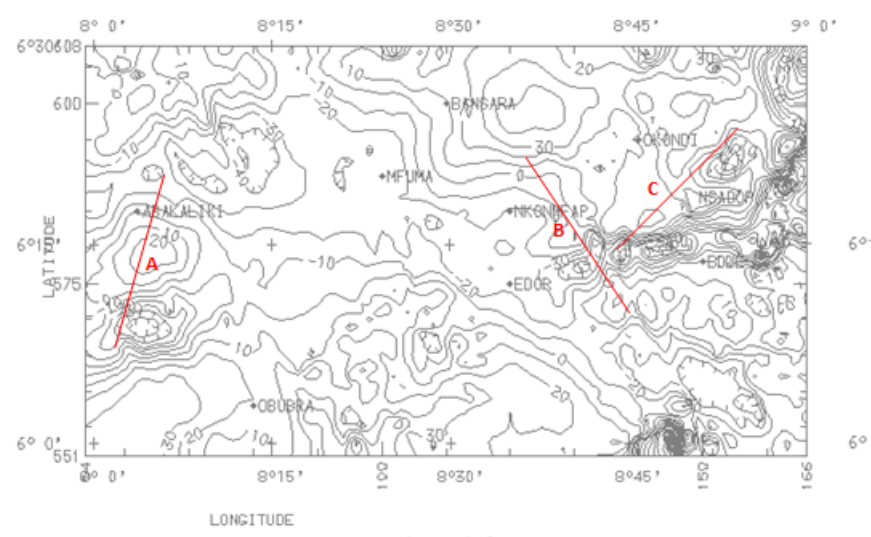

Fig. 4 RESIDUAL MAGNETIC ANOMALY MAP,BASED ON POLYNOMIAL FITTING OF REDUCED TO - THE - POLE MAP $($ CONTOUR INTERVAL $=10 \mathrm{nT})$

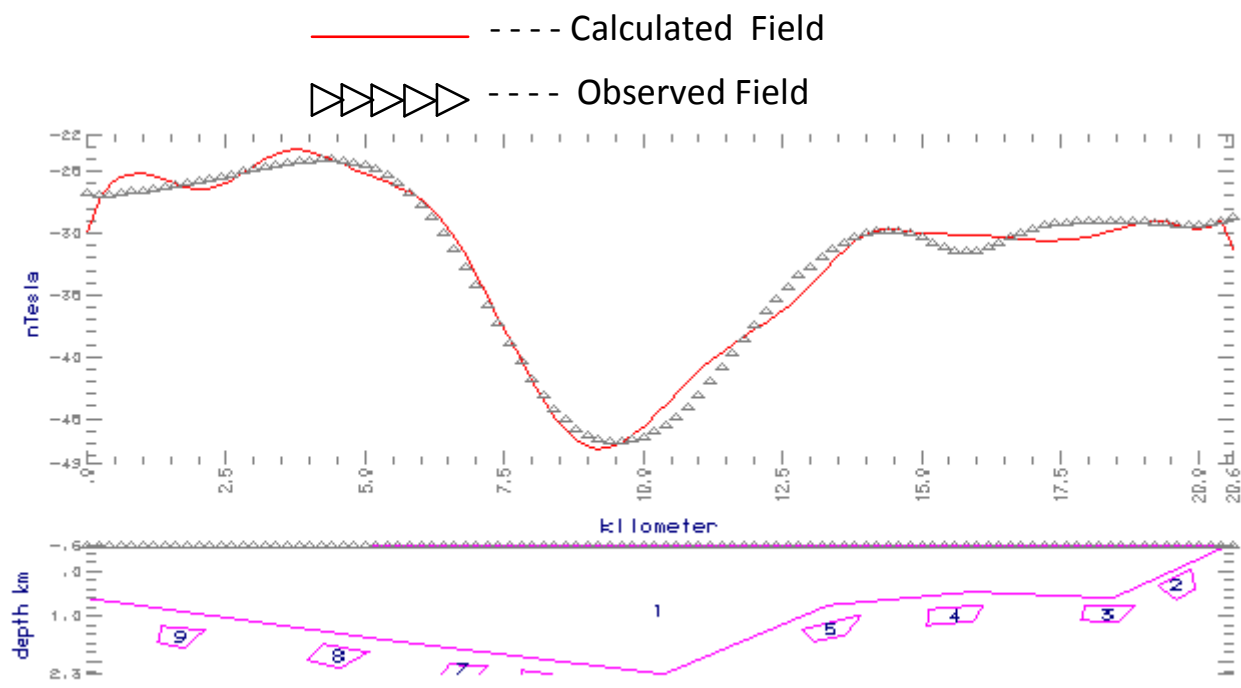

LEGEND: 1 = Sedimentary rocks

$2,3,4,5,8,9=$ Basement rocks magnetic

$6,7=$ Intrabasement intrusives

Fig.5 2.5D Forward and inverse modeled profile (A) along Abakaliki 


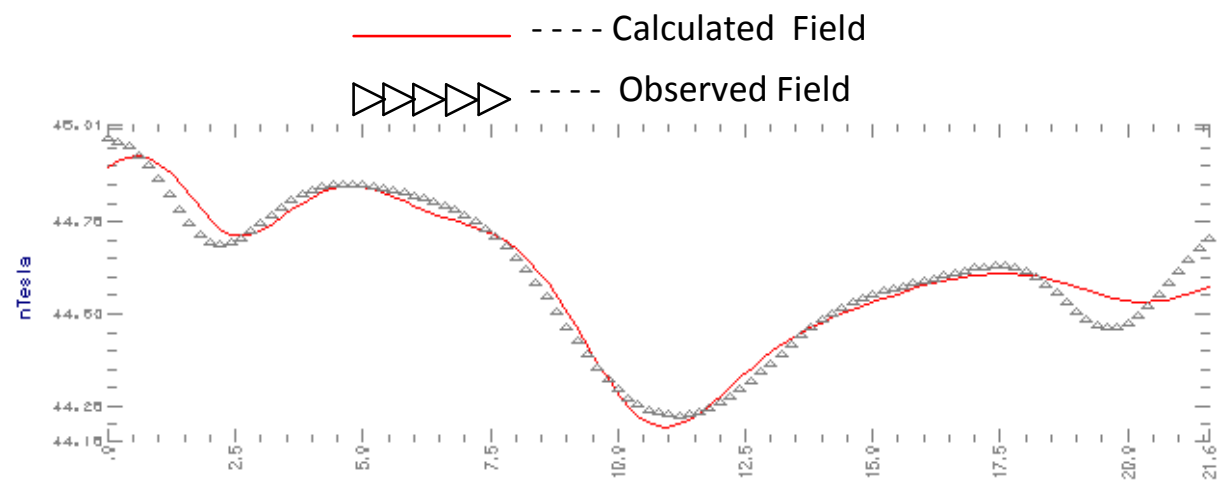

kl lometer

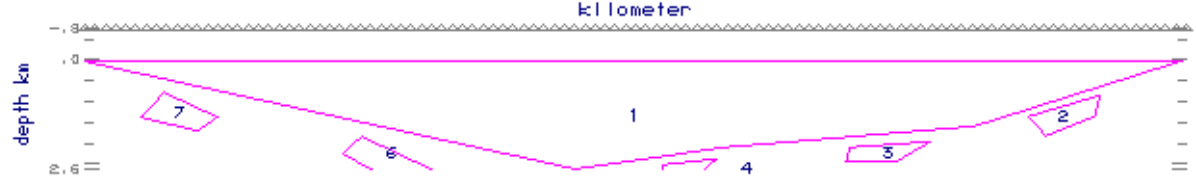

LEGEND: 1 = Sedimentary rocks

$2,3,7=$ Basement rocks magnetic

4,5,6 $=$ Intrabasement intrusives

Fig.6 2.5D Forward and inverse modeled profile (B) along Bansara - Nkom area.
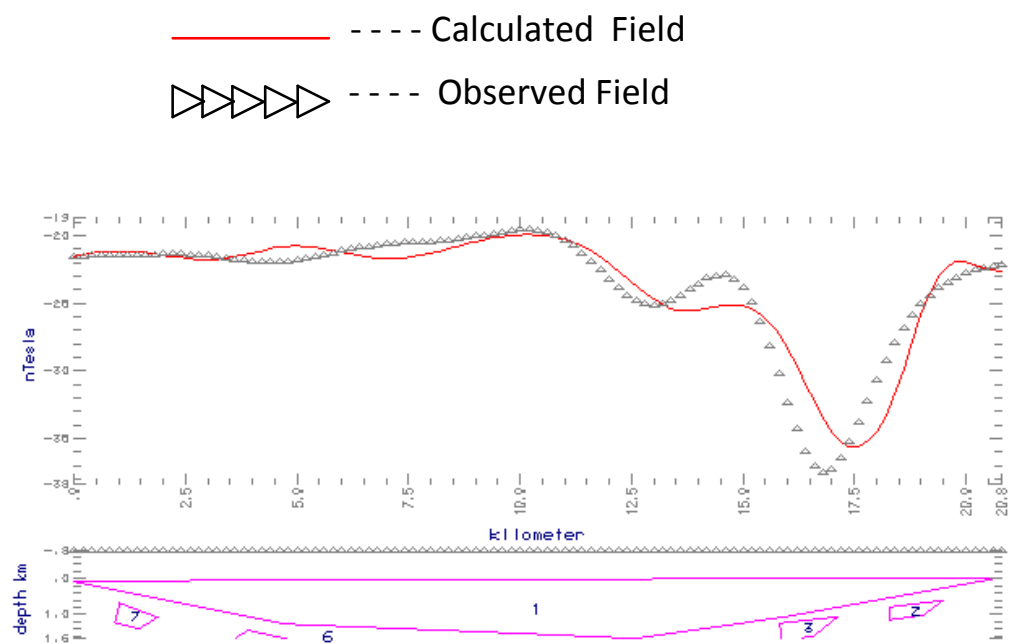

LEGEND: 1 = Sedimentary rocks

$2,3,6,7=$ Basement rocks magnetic

$4,5,=$ Intrabasement intrusives

Fig.7 2.5D Forward and inverse modeled profile (C) along Bansara -Nsadop along fault zone area.

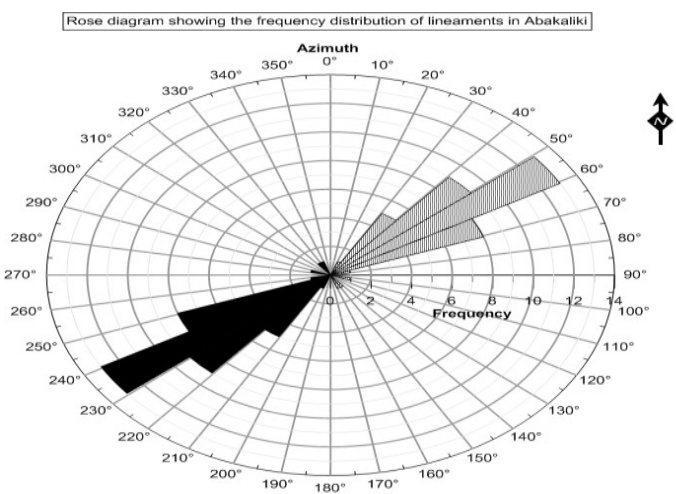

Scale: $1 \mathrm{~cm}=2 \%$

Fig. 8 a Rose diagrame showing the frequency distribution of lineaments in Abakaliki 


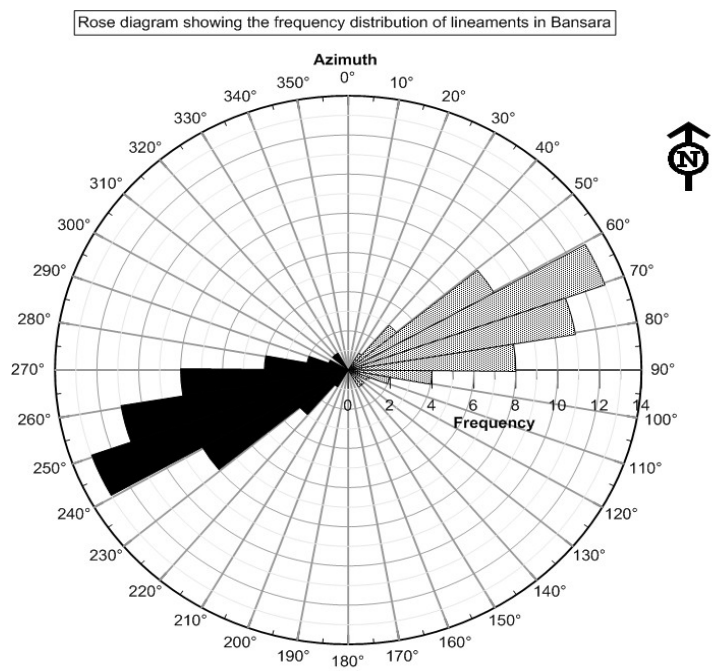

Scale: $1 \mathrm{~cm}=2 \%$

Fig.8b Rose diagrame showing the frequency distribution of lineament in Bansara

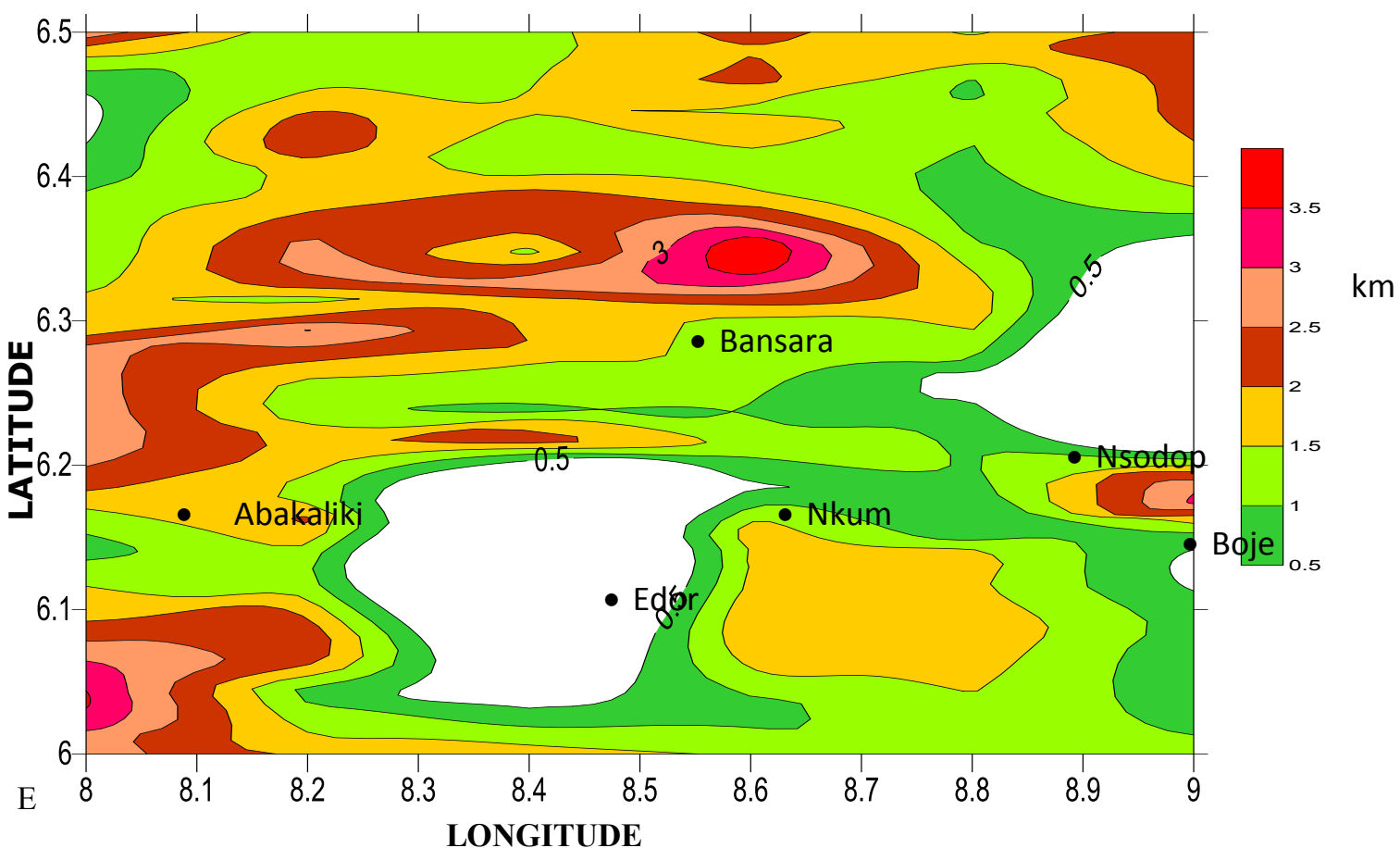

Fig. 9 MAGNETIC BASEMENT MAP IN KM, BASED ON MANUAL COMPUTATION METHOD $($ CONTOUR INTERVAL $=0.5 \mathrm{KM})$.

Table 1.0: Frequency Distribution of Lineament in Abakaliki Sheet

\begin{tabular}{|c|c|c|c|c|c|}
\hline $\mathbf{S} / \mathbf{N}$ & $\begin{array}{l}\text { Anomaly orientation } \\
\text { (degree }\end{array}$ & Frequency & $\begin{array}{l}\text { Length of } \\
\text { Anomaly } \\
(\mathrm{Li})(\mathrm{km})\end{array}$ & $\begin{array}{l}\text { Normalized } \\
\text { length } L i / L T\end{array}$ & $\begin{array}{lr}\text { Percentage } & \text { of } \\
\text { Normalized } & \text { length } \\
(\text { Li } / \text { LT } \times 100) \% & \\
\end{array}$ \\
\hline 1. & $1-10 / 181-190$ & - & - & - & - \\
\hline 2 & $11-20 / 191-200$ & - & - & - & - \\
\hline 3. & $21-30 / 201-210$ & 1 & 2.2 & 0.01224 & 1.2249 \\
\hline 4. & $31-40 / 211-220$ & 5 & 21.5 & 0.11971 & 11.9710 \\
\hline 5. & $41-50 / 221-230$ & 9 & 27.0 & 0.15033 & 15.033 \\
\hline 6. & $51-60 / 231-240$ & Obura & 63.2 & 0.35189 & 35.189 \\
\hline 7. & $61-70 / 241-250$ & 8 & 34.3 & 0.19098 & 19.098 \\
\hline 8. & $71-80 / 251-260$ & 1 & 14.5 & 0.08073 & 8.073 \\
\hline 9. & $81-90 / 261-270$ & - & - & - & - \\
\hline 10. & $91-100 / 271-280$ & - & - & - & - \\
\hline 11. & $101-110 / 281-290$ & 1 & 3.0 & 0.01670 & 1.6700 \\
\hline 12. & $111-120 / 291-300$ & - & - & - & - \\
\hline 13. & $121-130 / 301-310$ & - & - & - & - \\
\hline
\end{tabular}


Aeromagnetic Study of Oil Seepage along the Basement Flanks of Part of the Lower Benue Trough,

\begin{tabular}{|l|l|l|l|l|l|}
\hline 14. & $131-140 / 311-320$ & - & - & - & - \\
\hline 15. & $141-150 / 321-330$ & 1 & 47 & 0.02616 & 2.616 \\
\hline 16. & $151-160 / 331-340$ & 1 & 9.2 & 0.05122 & 5.1220 \\
\hline 17. & $161-170 / 341-350$ & - & - & - & - \\
\hline 18. & $171-180 / 351-360$ & - & - & - & - \\
\hline 19 & Total & 40 & 179.6 & 0.99996 & 99.9969 \\
\hline
\end{tabular}

Table 2.0: Frequency Distribution of Lineament Trends in Bausara Area

\begin{tabular}{|c|c|c|c|c|c|}
\hline $\mathbf{S} / \mathbf{N}$ & $\begin{array}{l}\text { Anomaly } \\
\text { orientation }\end{array}$ & Frequency & $\begin{array}{ll}\begin{array}{l}\text { Length } \\
\text { Anomaly }\end{array} & \text { of } \\
(\mathrm{km}) & \mathrm{Li} \\
\end{array}$ & $\begin{array}{l}\text { Normalized length of } \\
\text { Anomaly (Li/LT) }\end{array}$ & $\begin{array}{lr}\text { Percentage } & \text { of } \\
\text { Normalized Length } \\
(\text { Li/LT x 100) }\end{array}$ \\
\hline 1. & $1-10 / 181-190$ & - & - & - & - \\
\hline 3. & $21-30 / 201-210$ & & & & \\
\hline 4. & $31-40 / 211-220$ & 1 & 4.2 & 0.01347 & 1.347 \\
\hline 5. & $41-50 / 221-230$ & 3 & 13.3 & 0.04267 & 4.267 \\
\hline 7. & $61-70 / 241-250$ & 13 & 57.0 & 0.18287 & 18.287 \\
\hline 8. & $71-80 / 251-260$ & 11 & 82.0 & 0.26307 & 26.307 \\
\hline 9. & $81-90 / 261-270$ & 8 & 52.2 & 0.167369 & 16.7 \\
\hline 10. & $91-100 / 271-280$ & 4 & 17.8 & 0.057106 & 5.7106 \\
\hline 11. & $101-110 / 281-290$ & 2 & 13.3 & 0.042669 & 4.2669 \\
\hline 12. & $111-120 / 291-300$ & 1 & 4.7 & 0.015079 & 1.5079 \\
\hline 17. & $161-170 / 341-350$ & - & - & - & - \\
\hline 18. & $171-180 / 351-360$ & - & - & - & - \\
\hline 19 & Total & 53 & 311.7 & 0.999993 & 99.9993 \\
\hline
\end{tabular}

Table 3.0

\begin{tabular}{|c|c|c|c|c|c|c|c|c|c|c|c|c|}
\hline $\begin{array}{l}\text { Profile } \\
\text { Name }\end{array}$ & $\begin{array}{l}\text { Inclinat } \\
\text { ion }\end{array}$ & $\begin{array}{l}\text { Declinat } \\
\text { ion }\end{array}$ & $\begin{array}{l}\text { Azim } \\
\text { uth }\end{array}$ & $\begin{array}{l}\text { To } \\
\text { tal } \\
\text { fie } \\
\text { ld }\end{array}$ & $\begin{array}{l}\text { No of } \\
\text { Intrusi } \\
\text { ve }\end{array}$ & $\begin{array}{l}\text { No } \\
\text { of } \\
\text { Vert } \\
\text { ex }\end{array}$ & $\begin{array}{l}\text { No } \\
\text { of } \\
\text { bod } \\
\text { ies }\end{array}$ & $\begin{array}{l}\text { Dept } \\
\text { sedim } \\
\text { ent } \\
\text { thickn } \\
\text { ess }\end{array}$ & $\begin{array}{l}\text { Susceptibi } \\
\text { lity of } \\
\text { intrusives }\end{array}$ & $\begin{array}{l}\text { Type of } \\
\text { intrusives }\end{array}$ & $\begin{array}{l}\text { Rms } \\
\%\end{array}$ & $\begin{array}{l}\text { Dista } \\
\text { nce } \\
\mathrm{km}\end{array}$ \\
\hline $\begin{array}{l}\text { Abakali } \\
\text { ki }\end{array}$ & 12.7 & 6.0 & 173 & $\begin{array}{l}32 \\
53 \\
5\end{array}$ & 2 & 44 & 9 & $\begin{array}{l}0.8- \\
2.3\end{array}$ & $\begin{array}{l}0.0035 \\
0.0025\end{array}$ & $\begin{array}{l}\text { Gneiss/ } \\
\text { Rhyolite }\end{array}$ & 1.0 & 20.6 \\
\hline $\begin{array}{l}\text { Bausara } \\
\text { (Along } \\
\text { fault } \\
\text { zone) }\end{array}$ & 12.7 & 6.0 & 149.7 & $\begin{array}{l}32 \\
53 \\
5\end{array}$ & 2 & 30 & 7 & $\begin{array}{l}1.0- \\
1.6\end{array}$ & $\begin{array}{l}0.005 \\
0.025\end{array}$ & $\begin{array}{l}\text { Rhyolite } \\
\text { Basalt }\end{array}$ & 1.0 & 18.5 \\
\hline
\end{tabular}

